\title{
Letter to "Levothyroxine absorption test results in patients with TSH elevation resistant to treatment"
}

\author{
Sadettin Öztürk $\mathbb{D}^{1} \cdot$ Ersin Akarsu ${ }^{1}$
}

Received: 10 May 2021 / Accepted: 19 June 2021 / Published online: 20 July 2021

(c) The Author(s) 2021

We read the manuscript entitled "Levothyroxine absorption test results in patients with TSH elevation resistant to treatment" with great interest and pleasure [1]. We thought some points should be clarified so we decided to explain the test result discrepancies. İn the article to determine the absorbtion rate in patients with high levels of thyroid-stimulating hormone (TSH) despite receiving adequate doses of levothyroxine;

\% L4 absorbtion: [(peak $\Delta T 4 \times$ volume distribution) $\div$ administered dose of $\mathrm{LT}(\mu \mathrm{g})] \times 100$

Volume distribution $(d L): 4.42 \times$ body mass index

formula is used and according to the formula, those with an absorbtion result of more than $60-80 \%$ are considered normal. Considering the five patients evaluated in the study;

Absorption rates were not consistent with the data in the study Table 1 . In addition, very high peakT4 values are required for the $60-80 \%$ absorption rate required for the test to be normal. In the study named "The clinical utility of free

Table 1 LT4 absorption test result

\begin{tabular}{lllll}
\hline Patient & Basal fT4 $^{\mathrm{a}}$ & Peak fT4 & BMI $\left(\mathrm{kg} / \mathrm{m}^{2}\right)$ & Absorption (\%) \\
\hline 1 & 0.636 & 0.639 & 27 & $\mathbf{6}$ \\
2 & 0.290 & 0.440 & 27 & $\mathbf{4 0}$ \\
3 & 0.400 & 2.000 & 47 & $\mathbf{1 6 6}$ \\
4 & 0.200 & 1.300 & 26 & $\mathbf{9 7}$ \\
5 & 0.530 & 1.980 & 30 & $\mathbf{9 0}$ \\
\hline
\end{tabular}

${ }^{\mathrm{a}}$ Reference range of normal fT4 level is $0.89-1.76 \mathrm{ng} / \mathrm{dL}$

Patient 1: $[(0.639-0.636) \times 4.42 \times 27 \div 1000] \times 100=\% \mathbf{0 . 0 3 5}$

Patient 2: $[(0.440-0.290) \times 4.42 \times 27 \div 1000] \times 100=\% \mathbf{1 . 7 9}$

Patient 3: $[(2.000-0.400) \times 4.42 \times 47 \div 1000] \times 100=\% 33.2$

Patient 4: $[(1.300-0.200) \times 4.42 \times 26 \div 1000] \times 100=\% \mathbf{1 2 . 6 4}$

Patient 5: $[(1.980-0.530) \times 4.42 \times 30 \div 1000] \times 100=\% 19.27$

Bold values in the table from orjinal study

Sadettin Öztürk

sadettinozturk27@hotmail.com thyroxine in oral levothyroxine absorption testing", in which the formula is taken as reference, calculations were made with total T4 and free T4 values and it was observed that similar incompatibility was detected in the same way [2].

As a result, the reliability of this formula, which is used to evaluate the absorption of levotroxin in patients with persistent elevation of TSH despite levothyroxine replacement therapy, is controversial and there are studies in which an increase of $50-100 \%$ in basal free $\mathrm{T} 4$ is accepted to evaluate malabsorption [3].

\section{Compliance with ethical standards}

Conflict of interest The authors declare no competing interests.

Publisher's note Springer Nature remains neutral with regard to jurisdictional claims in published maps and institutional affiliations.

Open Access This article is licensed under a Creative Commons Attribution 4.0 International License, which permits use, sharing, adaptation, distribution and reproduction in any medium or format, as long as you give appropriate credit to the original author(s) and the source, provide a link to the Creative Commons license, and indicate if changes were made. The images or other third party material in this article are included in the article's Creative Commons license, unless indicated otherwise in a credit line to the material. If material is not included in the article's Creative Commons license and your intended use is not permitted by statutory regulation or exceeds the permitted use, you will need to obtain permission directly from the copyright holder. To view a copy of this license, visit http://creativecommons. org/licenses/by/4.0/.

\section{References}

1. IlginYildirim Simsir, UtkuErdem Soyaltin, AhmetGokhan Ozgen, Levothyroxine absorption test results in patients with TSH elevation resistant to treatment. Endocrine 64, 118-121 (2019)

2. GraceE.Ching Sun et al. The clinical utility of free thyroxine in oral levothyroxine absorption testing. Endocr. Pract. 20, 925-929 (2014)

3. KennethB. Ain et al. Pseudomalabsorption of levothyroxine. JAMA 266, 2118-2120 (1991) 